\title{
Tax incentives available to young people in agriculture: the Nigerian perspective
}

\author{
By Ninette Nyalyan Ninyio*
}

The Agricultural sector in every society around the globe, is regarded as one of the most viable investment opportunities due to its innate nature, revolving around the production and supply of food items for consumption. Agriculture plays a critical role in the entire life of a given economy. In addition to providing food and raw material, agriculture also provides employment opportunities to a very large percentage of the population. ${ }^{1}$

In Nigeria, the Federal Ministry of Agriculture and Rural Development ("the Ministry" or "FMARD") has the mandate to regulate the agricultural sector, ensure availability of agricultural produce, stimulate large-scale agricultural investment, oversee the production and supply of raw materials to agribusinesses, provide markets for the products of the industrial sector, formulate programmes, policies and actions to improve the agricultural sector, and issue regulatory permits and licenses. ${ }^{2}$

The ultimate goal of a business in agriculture as common with other businesses is wealth maximization and one reliable means of achieving this purpose is through cost minimization. Cost minimization is the process of reducing expenditures on unnecessary or inefficient processes. ${ }^{3}$ Cost minimization is a necessary condition for profit maximization in competitive markets. By analyzing operations and other areas of a business and stripping down to the most efficient, "lean and mean" processes, organizations are able to identify problem areas, change unproductive methods, streamline procedures and ultimately reduce costs significantly. This is necessary to ensure that a business remains profitable, and in good condition to carry out its business goals. Failure to remain profitable will ultimately lead to the winding down of such business.

It is without any peradventure that one of the toughest challenges faced by young people in the business environment is financing their businesses, and this problem is more pronounced when any income, or profit accrued by business entities owned by young people is made subject to tax remits.

Business entities subject to various regulations, are mandated to remit a certain percentage of its income as tax to the government, to promote public sector activities, and

* Ninette Nyalyen Ninyio, Associate at PAC Solicitors, Lagos, Nigeria, ninyioninette@gmail.com, +2347034221380 .

1 Agri News Net Portal, The importance of Agriculture, https://www.farmingportal.co.za/index.php/fa rminglifestyle/agri-tourism/195-the-importance-of-agriculture, accessed 12/9/2021.

2 Uche Matthew and Demilade Odutola, An Appraisal of the Regulatory Framework for Investment in the Nigerian Agricultural Sector http://www.spaajibade.com/resources/category/corporate- financ e-and-capital-market/, accessed 12/9/2021.

3 Competitive Analytics https://competitiveanalytics.com/cost-minimization, Accessed 12/9/2021. 
ordinarily this compulsory payment constitutes a major cost and serves as a barrier to the goal of wealth maximization for businesses in agriculture, thereby, threatening its growth and survival. Although other businesses equally pay tax, the taxation of businesses in agriculture should be minimal to promote agricultural growth for economic development. Many business owners have been forced out of business because taxation has eroded their profit margins with little or nothing left as dividends for owners thereby discouraging investors' willingness to supply the fund needed to stay in business. ${ }^{4}$

The general tax regime for business entities in Nigeria is comprised of the Companies Income Tax Act, Value Added Tax Act, Capital Gains Tax Act and the recent Finance Act 2019, which provide guidelines for the computation and remittance of tax for corporate bodies. The Federal Inland Revenue Service (FIRS) is the agency saddled with the responsibility of assessment and collection of tax accruing to the Federal Government of Nigeria. The Federal Capital Territory Internal Revenue Service (FCT IRS) charged with the responsibility of assessing and collecting certain taxes in the FCT, which also accrue to the Federal government.

It is noteworthy and commendable that several tax incentives have been created by the government in Nigerian to encourage individuals including the younger generation to venture into agriculture, and to ensure that Nigerians are discouraged from importing agricultural items that can be grown within the country. Inferably, an enabling atmosphere could be said to have been created in the agriculture business environment in Nigeria, and commendable efforts have continually been made to ameliorate the hardship faced by businesses especially in their early days, to allow such businesses find their feet, and set sail before they are welcomed into the 'real business world'. This usually takes the form of tax incentives and pioneer status which is granted for a specified period of time.

The Minister of Industry, Trade and Investment, Mr. Niyi Adebayo observed that country had recorded improvements in its business environment especially in the last five years, based on the World Bank's assessment through its Doing Business Index. According to him, Nigeria's ranking stood at 131 of 170 countries in 2020, up from 170 of 189 countries in 2016. ${ }^{5}$

The essence of the ease of doing business policies one of which is the creation of tax incentives, is to create an enabling environment for businesses to thrive, as thriving businesses have positive ripple effects on the growth of a nation's economy, whereby the adoption of new technologies is hardly preceded by the adoption and implementation of robust regulatory frameworks.

4 Tennyson Oghoghomeh, An Assessment of Agribusiness Tax Incentives in Nigeria, International Journal of Business and Economic Development (2014)(2)(1), https://www.google.com/search?clie $\mathrm{nt}=$ firefox-b-d\&q=tax+incentives + for+agriculture $+\mathrm{in}+$ nigeria, Accessed on 5/7/2021.

5 This Day Newspaper, https:/www.thisdaylive.com/index.php/2021/03/15/nigeria-to-improve-on-ea se-of-doing-business-ranking-by-2023/, Accessed on 5/7/2021. 
While there is no particular legal regime in Nigeria specially crafted for young persons involved in agriculture, one can reference the various general tax incentives for the agriculture industry, and by extension, apply them to young persons involved in agriculture.

One of the most common tax incentives as pertain agriculture is for Small or mediumsized companies engaged in primary agricultural production. These companies are eligible for an initial tax-free period of four (4) years which may be extended for an additional two (2) years period subject to satisfactory performance. Additionally, certain tax benefits are enjoyed by companies located in the rural areas which take the form of tax reductions at graduated rates for enterprises located at least 20 kilometres from available electricity, water, and tarred roads. ${ }^{6}$ These exemptions are laudable and highly beneficial for young persons involved in agriculture. There is a guarantee that for a small or medium sizes agricultural company, the obligation to pay tax is obviated for four years, subject to a further two years period. The nature of Agriculture entails that several agricultural enterprises will be situate in rural areas where there is availability of land for agricultural practice, and these locations may be well away from available electricity, water or tarred roads. In the event of any of these, such companies have tax incentives to aid in ameliorating the difficulties involved in situating agricultural businesses in such rural areas. By these, the room is created for focus and industry to be expended in activities that can maximise growth and expansion in such agricultural businesses away from the hassles of computing and paying tax rates annually.

Section 3(6)(c) \& (d) of the Industrial Development (Income Tax Relief Act) which provides for additional categories of investment that will qualify for tax relief as follows:

1. A company that invests in a rural area and provides infrastructures such as road, electricity, housing, water, etc. in the area may enjoy tax relief for up to 7 years.

2. A company with over $90 \%$ of locally sourced inputs/raw materials and whose investment is in Agriculture and Agro-processing may be able to enjoy tax relief for up to 15 years.

Agro and agro-allied businesses are tax free. This tax incentive/exemption extends to the payments of minimum tax by companies that make small or no profits at all do not apply to agro-allied business. Minimum tax is tax paid when a company makes a loss (normal business loss) in the year of assessment. Company Income Tax in years of loss, would not be computed on such loss, rather the company would be compelled to pay a minimum tax as specified in the Companies Income Tax Act.

Export processing zones (EPZs) and free trade zones (FTZs) are locations within Nigeria designated by the government as free areas where export trade activities can be carried on free of tax and foreign exchange restrictions. ${ }^{7}$ Additionally, an agricultural company that is engaged in an approved manufacturing activity in an Export Processing Zone and incurs

$6 P W C$, Nigeria Corporate Tax credits and incentives, https://taxsummaries.pwc.com/nigeria/corporat e/tax-credits-and-incentives Accessed on 5/7/2021.

7 Ibid. 
expenditures in its qualifying building and plant equipment is entitled to $100 \%$ capital allowance in that year of assessment. Similarly, an agricultural company that is $100 \%$ export oriented but located outside an Export Processing Zone will enjoy a three-year tax holiday, provided the company is not formed by splitting up or reconstruction of an already existing business and the export proceeds from at least $75 \%$ of its turnover. This provision is made to encourage new companies delve into manufacturing activities despite the cost involved. However, the tax exemption for free trade zone companies is subject to such companies filing income tax and transfer pricing (where applicable) returns to the FIRS.

It appears that in Nigeria, the incentives go as far as covering those companies who are involved in export of their manufactured agricultural products even though there is a condition attached. Profits of any Nigerian company in respect of goods exported from Nigeria are exempt from tax, provided that the proceeds from such exports are repatriated to Nigeria and are used exclusively for the purchase of raw materials, plant, equipment, and spare parts. ${ }^{8}$

\section{Exemption of Taxation on Interest on Loans.}

Interest payable on loans granted to any company engaged in agricultural trade or business is exempted from taxation, provided the moratorium does not exceed 18 months. ${ }^{9}$ In the same vein, interest accruing on loans granted to individuals engaged in agricultural trade or business is not subject to taxation. ${ }^{10}$ With this incentive on loans, there is less financial obligation/burden on agricultural businesses in terms of raising equity by taking loans, as no tax is to be paid on the interest that accrues to such loan. The borrower is focused on the repayment of the loan, the accrued interest, and nothing more.

\section{Exemption from Value Added Tax (VAT)}

Value Added Tax (VAT) in Nigeria is the tax payable on goods and services consumed by any person, whether government agencies, business organization, or individuals. ${ }^{11}$ It can also be described as a consumption tax applied at each stage of the transaction but ultimately borne by the final user of such products and services. VAT is charged at a rate of $7.5 \%{ }^{12}$

It is noteworthy that the importation and purchase of machinery/ equipment for agricultural production, agricultural processing or other agro-allied projects is exempted from value added tax and import duty tariffs under the auspices National Investment Promotion

8 Ibid.

9 Section 11(2) Companies Income Tax Act Cap. C21. L.F.N. 2004.

10 Section 19(7) Personal Income Tax Cap P8 L.F.N. 2004.

11 Resolution Law Firm, https://www.resolutionlawng.com/value-added-tax-in-nigeria/ Accessed 10/9/2021.

12 FIRS, https://www.firs.gov.ng/value-added-tax-vat/ Accessed 11/9/2021. 
Council. ${ }^{13}$ Agro-allied is defined as the industry that is closely related to cultivating soils, growing plants, and producing crops and cannot be successful without raw materials. ${ }^{14}$ Agricultural input including insecticides, rodenticides, fungicides, herbicides, anti-sprouting products, plant growth regulator, disinfectants as well as mechanical appliances for dispersing such substances are VAT exempt. ${ }^{15}$ The Finance Act 2019 has extended the list of goods and services exempted from VAT. The additional exemptions include basic food items - cereals, cooking oils, culinary herbs, fish, flour and starch, fruits (fresh or dried), live or raw meat and poultry, milk, nuts, pulses, roots, salt, vegetables, among others. ${ }^{16}$ This extremely laudable regulation has made it easier for young persons engaged in the identified agricultural items to have such items excluded from VAT, and thus allowing them vhannel resources into improving and expanding their enterprise.

\section{Pioneer Status}

Pioneer Status Incentive ("PSI") is designed to reduce the cost of doing business in Nigeria by providing corporate income tax relief to qualifying companies making investments in industries designated as "pioneer", and for it is expedient in the public interest, to encourage the development or establishment of such industry in Nigeria. In effect, PSI seeks to enhance the survival, profitability and sustainability of beneficiary companies. ${ }^{17}$ In other words, it is an incentive from the Nigerian government which exempts companies from the remittance of income tax for a certain duration of production. Qualifying industries and products listed as pioneer industries by the President, ${ }^{18}$ and which may be amended occasionally, are granted relief from the payment of corporate income tax for an initial period of three years, extendable for one or two additional years. ${ }^{19}$ On the delegated authority of the Minister of Industry, Trade and Investment, the National Investment Promotion Council is responsible for approving and extending PSI, and issuing pioneer certificates. ${ }^{20}$

13 https://www.nipc.gov.ng/opportunities/agriculture/ Accessed 15/9/2021.

14 Legit, "Meaning of Agro-allied and its synonyms", https://www.legit.ng/1146276-meaning-agro-al lied-synonyms.html, Accessed 10/9/2021.

15 Uche Matthew, Demilade Odutola, "Nigeria: An Appraisal Of The Regulatory Framework For Investment In The Nigerian Agricultural Sector", https://www.mondaq.com/nigeria/sales-taxes-vat -gst/1012966/an-appraisal-of-the-regulatory-framework-for-investment-in-the-nigerian-agricultura 1-sector, Accessed 08/9/2021.

16 Premium Times Newspaper, "presidency lists items exempted from VAT by Finance Act 2019", https://www.premiumtimesng.com/business/business-news/373412-presidency-lists-items-exempt ed-from-vat-by-finance-act.html, Accessed 10/9/2021.

17 Guideline 1.2, Application Guidelines for Pioneer Status Incentive, FRN Official Gazette, Vol. 104, 2017.

18 Section 1,Industrial Development (Income Tax Relief) Act.

19 Guideline 2.1, ibid.

20 Guideline 2.3.3, ibid. 
Pioneer Status is not automatic, as companies have to apply for pioneer status certificates to be issued to them. To qualify for the grant of a pioneer status certificate, the company must be engaged in the pioneer industry; and must have Qualifying Capital Expenditure (QCE) worth over N100 million for an indigenous controlled company, and In the case of any other company, QCE should not be less than N 120 million; and must be able to show the positive impact its business will have on the Nigerian economy. ${ }^{21}$ This QCE requirement is provided for in the Industrial Development (Income Tax Relief) Act (Amendment) Bill 2018 (The Bill) passed by the Senate on 12 April 2018. ${ }^{22}$

For clarity, Capital expenditures refer to funds that are used by a company for the purchase, improvement, or maintenance of long-term assets to improve the efficiency or capacity of the company, and these are usually physical, fixed and non-consumable assets such as property, equipment, or infrastructure ${ }^{23}$

Processing of agricultural produce is also a pioneer industry in Nigeria. The Federal Executive Council vide an Official gazette No. 84, Volume 104 published on $14^{\text {th }}$ August 2017, approved livestock, crop production, fishing and forestry (plantation of rubber and acacia trees) as well as the manufacture of grain mill, dairy, starch product, coffee, cocoa, edible oil and a host of others, as pioneer industries. Consequently, there is $100 \%$ tax-free period for 5 years for projects into processing of agricultural produce. The idea of granting pioneer status to the agriculture industry to enable more efficient product processing and delivery, is laudable. However, the Qualifying Capital Expenditure benchmark of 100 million for indigenous companies appears anti-climactic, and places young persons who are involved in agriculture, or who possess such intent, at a disadvantage. It would also be reasonable to argue that the Qualifying Capital Expenditure requirement makes accessibility restricted to persons with considerable financial capacity. There are concerns that Small and Medium Scale Enterprises may not be able to take advantage of the Scheme because of the increment in the threshold for Qualifying Capital Expenditure from N10million as provided in the Pioneer Status Incentive Regulations to N100million or N120million as the case may be. ${ }^{24}$

It is suggested that the Qualifying Capital Expenditure benchmark be drastically altered to a lower figure as previous in the Pioneer Status Incentive Regulations, so as not to disqualify young persons by default, from the ability to partake in the Pioneer Status Incentive scheme. This will serve as a catalyst in the proliferation of agricultural activities by young persons considering the state of the economy, and cost of living in Nigeria.

21 Seun Timi- Koleolu and Eustace Aroh, "Tax Incentives in Nigeria”, https://pavestoneslegal.com/ta x-incentives-in-nigeria-pioneers-status/, Accessed on 21/9/2021.

22 Andersen “Tax Alert”, https://ng.andersen.com/senate-passes-industrial-development-itr-act-2018/ accessed on 19/9/2021.

23 Corporate Finance Institue, "Capital Expenditure”, https:/corporatefinanceinstitute.com/resources/ knowledge/accounting/capital-expenditures/, Accessed on 19/9/2021.

24 Ibid. 


\section{Minimum Local Raw Materials Utilization.}

Raw materials, including ingredients, processing aids, and packaging, are the foundation of finished food products. ${ }^{25}$

In Nigeria, industries were heavily dependent on imported raw materials. ${ }^{26}$ To address this challenge, the Raw Materials Research and Development Council (RMRDC), an agency of the Federal Government of Nigeria (under the supervision of Federal Ministry of Science and Technology) was established by Decree (now Act) 39 of 1987, and was vested with the mandate to promote the development and utilization of Nigeria's industrial raw materials. ${ }^{27}$

To encourage minimum local raw material utilization, a tax credit of $20 \%$ is granted for five years to industries that attain the minimum level of local raw material sourcing and utilization. Once an Agro-allied industry attains the minimum levels of local materials sourcing \& utilization, it is entitled to enjoy tax credit. Section 3(6) (d) of the Industrial Development Income Tax Relief (Amendment) Act 2018 provides as follows;

- a company with over $90 \%$ of locally sourced inputs/raw materials and whose investment is in Agriculture and Agro-processing may be able to enjoy tax relief for up to 15 years.

As expressed by the Federal Ministry of Agriculture, Water Resources and Rural Development, the Government's strategy on Agriculture includes ensuring maximum capacity utilization in and the expansion of existing plants, to encourage the establishment of new plants to encourage the use of local raw materials for fertilizer production and to encourage the use of organic fertilizers by farmers. This policy also extends to the manufacture agro-chemicals and the livestock industry. ${ }^{28}$

This tax relief in a nutshell rewards persons engaged in agriculture who source the requisite minimum percentage of raw materials locally.

\section{Conclusion}

Agriculture contributes 47 per cent to the country's Gross Domestic Product (GDP) and is responsible for 10 per cent of its export earnings. ${ }^{29}$ The Federal Government over the years, has recognized the importance of the agriculture industry to the nation's economy, and created fairly robust tax incentives for the industry which have been highlighted above.

25 Quality Assurance and Food Safety, https://www.qualityassurancemag.com/article/aib0613-raw-m aterials-requirements/ Accessed 30/9/2021.

26 RMRDC, https:/www.rmrdc.gov.ng, Accessed 20/19/2021.

27 Ibid.

28 Federal Ministry of Agriculture, Water Resources and Rural Development, Agricultural Policy for Nigeria, http://extwprlegs1.fao.org/docs/pdf/nig149296.pdf, accessed 21/9/2021.

29 Industrial Renaissance, Agribusiness Incentives, www.indusren.com/incentives-and-guarantees/ag ribusiness/, Accessed 19/9/2021. 
These are laudable and are placed alongside other non-tax incentives to be taken advantage of by young persons in the agriculture sector.

The above highlighted tax incentives are programs that help create an enabling business atmosphere for young persons involved in agriculture. They help to better guarantee a greater chance for success as the players in the agriculture industry are not burdened with tax obligations, especially at commencement giving them the opportunity to establish a foothold, and enhance growth.

As earlier suggested, it is necessary to alter the QCE requirements for pioneer status incentives, as pertain agriculture. This will encourage young persons to engage more in the sector, and invest capital and industry in a very critical sector of the nation's economy, especially considering the drop in the global price of crude oil which is the nation's major revenue generation avenue.

Finally, with proper sensitization on the existence of these incentives by the relevant Federal Government Agencies, it is reasonable to assert that younger persons will venture into agriculture, to take advantage of these incentives in growing businesses that will contribute in a greater capacity to the growth and positive development of the nations' economy. The need for an increased concerted sensitization and enlightenment of the public about these available incentives in the agricultural sector, is not limited to Government agencies, but extends to business interest groups, educational institutions among others. Until this is done, the purpose, and vision behind the creation of the various highlighted incentives, may scarcely be achieved. 